\title{
The role of small and medium enterprises in managing intellectual property in Kenya: A case of gifted hands
}

\section{JOB BOITT NGETICH}

Msc. Entrepreneurship, Jomo Kenyatta University of Agriculture and Technology, Nairobi, Kenya

Email address:

boitt@hotmail.com

\section{To cite this article:}

JOB BOITT NGETICH. The Role of Small and Medium Enterprises in Managing Intellectual Property in Kenya: A Case of Gifted Hands. Science Journal of Business and Management. Vol. 1, No. 4, 2013, pp. 74-80. doi: 10.11648/j.sjbm.20130104.13

\begin{abstract}
Intellectual property delivers core competencies, which fuels long-term sustainable competitive advantage. This study sought to determine the role of SME's in managing intellectual property in Kenya. The study was done on one organization to allow an in-depth analysis. To achieve the main objective of this study, the study was guided by four specific objectives including the determination of how Small and Medium Enterprises create awareness on intellectual property management in Kenya; establishing the extent to which Small and Medium Enterprises fund intellectual property management in Kenya; determining how Small and Medium Enterprises assist the government in formulating policies on intellectual property management in Kenya and establishing the contribution of Small and Medium Enterprises to innovation and inventions in Kenya. The research adopted a descriptive survey. Descriptive research design was chosen because it enabled the researcher to generalise the findings to a larger population. The population of this study comprised the employees at Gifted Hands Limited. From study findings, the study concludes that community workshops should be held to raise awareness of the economic importance of intellectual property and to increase stakeholders' participation in the intellectual property policy making process. Further the study concludes that to be acceptable, any system of intellectual property rights has to strike a balance on the one hand, between providing incentives and rewards to the rights holder and on the other hand facilitate access to, and widespread diffusion and adoption of the fruits of creativity and innovation. Finally, in order for a firm to effectively manage its intellectual property it needs to establish a comprehensive policy which will provide guidelines on how to handle intellectual property and that the costs of patenting are generally perceived as one of the greatest barriers for SME.
\end{abstract}

Keywords: Role of Small and Medium Enterprises, Gifted hands, Intellectual Property, Creativity and Innovation, Kenya

\section{Introduction}

Intellectual property is described as an intangible creation of the human mind; usually it is converted into a tangible form that is assigned certain rights of property (Jolly and Philpott 2004). Sange (2010) depicts it as a creation of the human intellectual process and is therefore a product of the human mind. According to Sople (2006) he defines intellectual property as property in legal sense that can be sold, leased or licensed. Innovation is in general a key focal point when explaining economic growth and the Kenyan Small and Medium enterprises (SME) is no exception. Intellectual property rights (IPRs), for example patents, play an important role in this innovative market, affecting the diffusion of knowledge, innovation process and economic efficiency.
The effective management of intellectual property as well as developed intellectual property system has a resounding impact on the strength and survival of a firm as well as the economy at large. Intellectual property has long been recognized and used by industrialized countries, and some developing countries, as an important tool of technological and economic development (Sange, 2010). The contribution of knowledge-intensive industries to gross national product is increasing (from $21 \%$ to $27 \%$ in the US from 1982-1995) and there is a noticeable upward trend in patent applications and grants worldwide, including in developing countries (Maskus, 2000). The increasing use of the intellectual property system by local businesses in dynamic economies such as China $(87.1 \%$ of approved invention, utility model, design patents by end 2004 were from local applicants) and Brazil (40\% of all Brazilian 
applications originate in Brazil), coupled with the $70.6 \%$ rise in international patent applications under the Patent Cooperation Treaty filed by developing countries in 2001, attests to this (Idris, 2003).

Intellectual property delivers core competencies, which fuels long-term sustainable competitive advantage. Effective protection and management of intellectual property rights is the key to continuity of a firm. Yet, it is difficult to think of another corporate asset that is subject to such careless guardianship (Jolly and Philpott, 2004). Intellectual property should become an integral part of the corporate strategy. In Kenya, there have been a number of cases which have stressed the need for effective intellectual property management. On the global scene, there are some international companies which have moved in to patent products which have deep roots in Kenya, such as the kiondo and the kikoi (Sange, 2008). In addition, there is the case of the bicycle dynamo mobile charger developed by two university students Pascal Katana and Jeremiah Murimi from the University of Nairobi, only for Nokia to introduce into the market a similar product within a short period (Kiberenge, 2010). The most current case of patent tussle involved the M-kesho services which saw Faulu Kenya take Safaricom to court for the name ownership. There is also the controversial case between the Tamarind Group, the owners of Carnivore and a local businessman, Boniface Muema Ndangili over ownership of the name 'Kililimbi nite'(Kiplagat,2010). Kenyan industries have also been facing colossal challenges because of counterfeiting. This negatively affected foreign direct investment and discouraged the growth of local entrepreneurship. It is estimated that right holders in Kenya lose an estimated 30 billion shillings per annum to trade in counterfeit and piracy (Office of the Attorney General, 2007). According to the Kenya Revenue Authority, counterfeiting costs the government 6 billion shillings in lost revenue annually (Office of the Attorney General, 2007). Gifted hands as an organization is involved in the development of hand craft artifacts. The organization has invested heavily in innovations which have seen it develop several original artifacts for sale. However, due to delays in patenting the innovation, the organization has ended up losing millions as their products get patented by other organizations and artisans who produce in masses and flood the market. This has been a serious challenge to the organization as it becomes difficult for it to recover its initial outlay. To reduce the effects of counterfeiting and protect its innovations, Gifted Hands has partnered with the Kenya Copyright Board to promote the protection of its intellectual property. Limited research has been conducted on the subject of intellectual property protection especially on the role small scale business in the protection of intellectual property in Kenya. This study therefore aimed to investigate the role of Small and Medium Enterprises' in the management of Intellectual Property in Kenya. The general objective of this study was to determine the role of Small and Medium Enterprises in managing intellectual property in Kenya. Specifically the study sought to

1. To determine the influence of Small and Medium Enterprises on awareness creation on intellectual property management in Kenya.

2. To establish the extent to which Small and Medium Enterprises fund intellectual property management in Kenya.

3. To determine how Small and Medium Enterprises assist the government in formulating policies on intellectual property management in Kenya

4. To Establish the influence of Small and Medium Enterprises on innovation and inventions in managing intellectual property in Kenya

\section{Theoretical Review}

\subsection{Locke's Property Theory}

Locke begins the discussion by describing a state of nature in which goods are held in common through a grant from God (Steiner, 2009). God grants this bounty to humanity for its enjoyment but these goods cannot be enjoyed in their natural state as the individual needs to convert these goods into private property by exerting labor upon them (Stevens, 1996). Although normally understood as descriptive of the common, the enough and as good condition also is conceptually descriptive of human beings (Maskus, 2000).

\subsection{Personhood Theory}

The personhood justification for property derives from Kant's Philosophy of Law and Hegel's Philosophy of Right and has been elaborated in modern legal discourse in the work of Radin $(1982,1993)$. 'The premise underlying the personhood perspective is that to achieve proper development - to be a person - an individual needs some control over resources in the external environment. The necessary assurances of control take the form of property rights' (Radin, 1982). The personhood justification for property emphasizes the extent to which property is personal as opposed to fungible: the justification is strongest where an object or idea is closely intertwined with an individual's personal identity and weakest where the 'thing' is valued by the individual at its market worth. For general critique of this theory, see Schnably (1993), Simmons (1992).

\subsection{Libertarian Theories}

Palmer (1989, 1990) constructs a libertarian argument against intellectual property rights by critiquing the dominant philosophical perspectives used to justify intellectual property protection. Coming from a different intellectual tradition, but reaching a similar conclusion, Barlow (1994) argues that intellectual property rights threaten to undermine free exchange of ideas over the Internet and enable corporate interests to exercise substantial control over cultural and political expression. 
Netanel (1996, pp. 365-385) suggests that these concerns can be addressed better through reworking rather than discarding copyright law. Waldron (1993) points out that autonomy as ideal cuts both for and against intellectual property rights. Authors may claim that the integrity of their self-expression requires that they control the use and adaptation of their works. Social commentators may argue, however, that they are denied the ability to express themselves if they cannot parody the works of others.

\subsection{Conceptual Framework}

A conceptual framework is a diagrammatical presentation of the independent and dependent variables and the relationship among themselves (Mugenda and Mugenda, 2003). This enables the reader to not only have a snapshot but clear understanding of what the study seeks to establish (Mugenda and Mugenda, 2003). The conceptual framework of the study will consist of the independent variables including the awareness creation, funding, policy formulation and innovation and inventions. The dependent variable will comprise of management of intellectual property in Kenya.

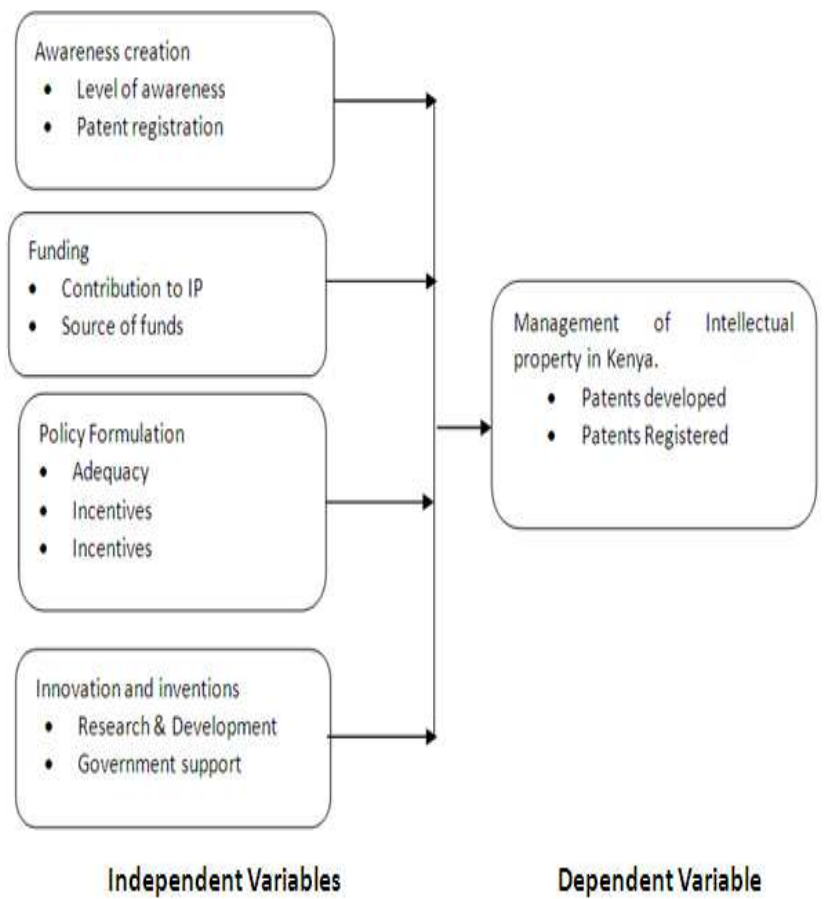

\subsection{Empirical Review}

It is crucial that the intellectual property policy is congruent with an organization's corporate goals. In the process of creating an effective intellectual property policy it is in order for the organization to identify its mission, business objectives, core functions and relevant policies which is essential for determining the organization's intellectual property management needs (Alikhan and Mashelkar, 2004).A good intellectual property policy should define intellectual property ownership, outline patenting policy, describe the manner in which an institution will handle confidential information, set out principles of its licensing and marketing approaches, explain how income from intellectual property will be distributed and delineate the rights and obligations of inventors and the institution as well as any rights the institution the institution will retain (Kratigger, 2007).

\subsection{Research Gaps}

This chapter reviewed the relevant literature in relation to the research questions presented in this study. (Kamiyama, Sheetan and Martinez, 2007). Ledergerbe (2003) argues that the costs of patenting are generally perceived as one of the greatest barriers for SME. In budgeting the costs relating to the acquisition of intellectual property rights, companies need to take into consideration not only the official fees (including application fees, publication fees and maintenance fees) but also the costs relating to application preparation and prosecution, legal advice and translation costs whenever the applicant intends to apply for protection abroad. From the above literature, it is evident that limited literature is available on the role of Small and Medium Enterprises in the management of intellectual property. This study therefore seeks to fill this research gap.

\subsection{Data Analysis and Presentation}

Data collected was analyzed by means of Statistical Package for the Social Sciences (SPSS) and is presented through percentages, means, standard deviations and frequencies. The information was displayed by use of bar charts, pie charts and frequency tables The study used both descriptive and inferential techniques, descriptive techniques used were frequencies whereas inferential techniques used was the linear regression analysis which sought to find out the relationship between the independent and dependent variables. The researcher further conducted a regression analysis to determine the relationship between the independent variables and the dependent variable. The following multiple regression model was applied in order to determine the role of Small and Medium Enterprises in managing intellectual property in Kenya, the researcher conducted a multiple regression analysis using the following model $Y=\beta_{0}+\beta_{1} X_{1}+\beta_{2} X_{2}+\beta_{3} X_{3}+\beta 4 X 4_{+} \varepsilon$

\subsection{Data Presentation}

The analyzed data was presented using frequency tables, graphs, pie charts and measures of central tendency including mean and standard deviations. For the likert scale type of questions, the study computed the mean and standard deviations.

\section{Results}

The study targeted all the 78 employees at gifted hands. Out of 78 questionnaires administered, a total of 64 filled 
questionnaires were filled and returned giving a response rate of $82 \%$ which is within Mugenda and Mugenda (2003) prescribed significant response rate for statistical analysis, which they established at a minimal value of $50 \%$. This commendable response rate was made possible by the use of research assistants who administered the questionnaires and made subsequent calls and visits to remind the respondents to fill in the questionnaires.

\subsection{Reliability Analysis}

Reliability Coefficients

\begin{tabular}{lcc}
\hline Scale & Cronbach's Alpha & Number of Items \\
\hline Awareness Creation & 0.821 & 10 \\
Funding & 0.797 & 9 \\
Policy Formulation & 0.848 & 7 \\
Innovation and Inventions & 0.713 & 8 \\
\hline
\end{tabular}

Reliability of the questionnaire was evaluated through Cronbach's Alpha which measures the internal consistency. Cronbach's alpha was calculated by application of SPSS for reliability analysis. The value of the alpha coefficient ranges from 0-1 and may be used to describe the reliability of factors extracted from dichotomous and or multi-point formatted questionnaires or scales. A higher value shows a more reliable generated scale. Cooper \& Schindler (2008) has indicated 0.7 to be an acceptable reliability coefficient. Table ... shows that policy formulation had the highest reliability $(\alpha=0.848)$ followed by awareness creation $(\alpha=0.821)$, then funding $(\alpha=0.797)$ and innovation and inventions $(\alpha=0.713)$. This illustrates that all the four scales were reliable as their reliability values exceeded the prescribed threshold of 0.7 .

Categories of Awareness Creation

\begin{tabular}{lcc}
\hline Awareness creation & Mean & Std Deviation \\
\hline Technological innovations & 4.112 & .345 \\
Administrative innovations & 2.932 & .945 \\
Human-resources innovations & 3.212 & .867 \\
Product/service innovations & 3.693 & .787 \\
\hline
\end{tabular}

From the findings on the extent to which the businesses engage in the various categories of awareness creation, the study found that majority of the respondents said that the businesses engage in the following to a great extent; technological innovations as shown by a mean of 4.0 and product/service innovations as shown by mean of 3.6 , respondent further rated the following to moderate extent; Human-resources innovations as shown by mean of 3.2 and administrative innovations as shown by mean of 2.9 , this was supported by low standard deviation an indication that respondent held similar opinions. According to (KEEP), community workshops should be held to raise awareness of the economic importance of intellectual property and to increase stakeholders' participation in the intellectual property policy making process.

\section{Strategic Reasons of Patenting}

\begin{tabular}{lcc}
\hline Strategic reasons of patenting & Mean & $\begin{array}{c}\text { Std } \\
\text { Deviation }\end{array}$ \\
\hline $\begin{array}{l}\text { For use in negotiations (e.g. cross-licensing) to } \\
\text { enhance reputation }\end{array}$ & 3.848 & .729 \\
$\begin{array}{l}\text { For use in generating licensing revenue and } \\
\text { measure performance }\end{array}$ & 4.286 & .362 \\
$\begin{array}{l}\text { Defensive applications (e.g. prevent competitors } \\
\text { from entering markets, enforcing patents against } \\
\text { infringers) }\end{array}$ & 3.769 & .366 \\
$\begin{array}{l}\text { Exploitation as a financial asset (i.e. to attract } \\
\text { external sources of finance) }\end{array}$ & 3.803 & .969 \\
$\begin{array}{l}\text { Exploitation as part of business and } \\
\text { management's strategy (e.g. licensing, building } \\
\text { a patent portfolio) }\end{array}$ & 3.848 & .723 \\
\hline
\end{tabular}

On the respondent rating the importance of various strategic reasons of patenting in the organization, the study revealed that majority of the rated the following as importance; for use in generating licensing revenue and measure performance as shown by mean of 4.286, exploitation as part of business and management's strategy (e.g. licensing, building a patent portfolio) and for use in negotiations (e.g. cross-licensing) to enhance reputation as shown by mean of 3.848 in each case, exploitation as a financial asset (i.e. to attract external sources of finance) as shown by mean of 3.803 and defensive applications (e.g. prevent competitors from entering markets, enforcing patents against infringers) as shown by mean of 3.769 .

\begin{tabular}{lcc} 
& Funding Extent & Percent \\
\hline & Frequency & $2 \%$ \\
To a very great extent & 1 & $7 \%$ \\
To a great extent & 3 & $22 \%$ \\
To a moderate extent & 9 & $51 \%$ \\
To a little extent & 21 & $17 \%$ \\
To no extent & 7 & $100 \%$ \\
Total & 41 & \\
\hline
\end{tabular}

From the study finding on the extent to which Small and Medium Enterprises fund intellectual property management, the study revealed that $51 \%$ of the respondent indicated to a little extent , $22 \%$ indicated to a moderate extent , $17 \%$ of the respondent indicated to a no extent , $7 \%$ of the 
respondent indicated to a great extent whereas $2 \%$ of the respondent indicated to a very great extent, this is an indication that Small and Medium Enterprises fund intellectual property management to a little extent .

Policies Formulating

\begin{tabular}{lcc}
\hline & Mean & $\begin{array}{c}\text { Std. } \\
\text { Deviation }\end{array}$ \\
\hline $\begin{array}{l}\text { There been incidences of employees selling } \\
\text { the companies intellectual property trade } \\
\text { secrets to competitors }\end{array}$ & 1.478 & .317 \\
$\begin{array}{l}\text { Your employees have been approached by } \\
\text { competitors with better job offers in order to } \\
\text { reveal the organization's intellectual property }\end{array}$ & 1.321 & .224 \\
$\begin{array}{l}\text { Counterfeiting and piracy are a huge threat to } \\
\text { the survival of your organization }\end{array}$ & 1.311 & .796 \\
$\begin{array}{l}\text { The organizations charged with intellectual } \\
\text { property protection are discharging their } \\
\text { duties effectively and efficiently }\end{array}$ & 2.082 & .131 \\
$\begin{array}{l}\text { The intellectual property laws in Kenya are } \\
\text { adequate to protect your organization's } \\
\text { intellectual property }\end{array}$ & 3.956 & .851 \\
\hline
\end{tabular}

From the findings on the respondent level of agreement on various statements on Government in policy formulation on intellectual property, the study found that majority of the respondent strongly agreed that counterfeiting and piracy are a huge threat to the survival of your organization as shown by mean of 1.311 , their employees have been approached by competitors with better job offers in order to reveal the organization's intellectual property as shown by mean of 1.321 and there been incidences of employees selling the companies intellectual property trade secrets to competitors as shown by mean of 1.478 , respondent agreed that the organizations charged with intellectual property protection are discharging their duties effectively and efficiently as shown by mean of 2.082, respondent disagreed that the intellectual property laws in Kenya are adequate to protect your organization's intellectual property as shown by mean of 3.956 .

Innovation Adoption

\begin{tabular}{lcc}
\hline innovation adoption & Mean & Std Deviation \\
\hline Education & 4.435 & .386 \\
Capital resource & 4.570 & .363 \\
Government legislation and regulation & 4.378 & .970 \\
\hline
\end{tabular}

From the findings on the extent to which various factors affect the innovation adoption in the Small and Medium businesses, the study found that capital resource affected innovation to very great extent as shown by men of 4.570 , those that affected innovation to great extent were education as shown by mean of 4.435 and government legislation and regulation as shown by mean of 4.378 .

Business Engagement in Innovation adoption

\begin{tabular}{lcc}
\hline & Mean & Std Deviation \\
\hline Technological innovations & 3.854 & .864 \\
Administrative innovations & 3.759 & .632 \\
Human-resources innovations & 3.743 & .370 \\
Product/service innovations & 4.435 & .416 \\
\hline
\end{tabular}

From the findings on the extent to which businesses engage in the various categories of innovation adoption, the study found that SMEs engage in the following innovation to great extent product/service innovations as shown by mean of 4.435 , technological innovations as shown by mean 3.854, administrative innovations as shown by mean of 3.759 and human-resources innovations as shown by mean 3.743 .

\section{Regression Analysis}

\begin{tabular}{ccccc}
\multicolumn{5}{c}{ Model Summary } \\
\hline Model & $\mathbf{R}$ & $\begin{array}{c}\mathbf{R} \\
\text { Square }\end{array}$ & $\begin{array}{c}\text { Adjusted R } \\
\text { Square }\end{array}$ & $\begin{array}{c}\text { Std. Error of the } \\
\text { Estimate }\end{array}$ \\
\hline 1 & $.969^{\mathrm{a}}$ & .939 & .921 & .01575 \\
\hline
\end{tabular}

Adjusted R squared is coefficient of determination which tells us the variation in the dependent variable due to changes in the independent variable. From the findings in the above table, the value of adjusted R squared was 0.969 , an indication that there was variation of $92.1 \%$ on the management of intellectual property of SMEs of due to changes in funding, awareness creation, policy formulation and innovation and invention at 95\% confidence interval . This shows that $92.1 \%$ changes in management of intellectual property of SMEs of could be attributed to changes in funding, awareness creation, policy formulation and innovation and invention. $\mathrm{R}$ is the correlation coefficient which shows the relationship between the study variables. The findings show that there was a strong positive relationship between the study variables as shown by 0.969 .

ANOVA $^{a}$

\begin{tabular}{llccccc}
\hline Model & $\begin{array}{c}\text { Sum of } \\
\text { Squares }\end{array}$ & df & $\begin{array}{c}\text { Mean } \\
\text { Square }\end{array}$ & F & Sig. \\
\hline & Regression & 0.002 & 2 & .001 & 3.869 & $.015^{\mathrm{b}}$ \\
1 & Residual & 0.609 & 61 & .021 & & \\
& Total & 0.611 & 63 & & & \\
\hline
\end{tabular}

From the ANOVA statistics in table above, the processed data, which is the population parameters, had a significance level of 0.015 which shows that the data is ideal for making 
a conclusion on the population's parameter as the value of significance (sign -value ) is less than 5\%. The calculated was greater than the critical value $(2.262<3.869)$ an indication that funding, awareness creation, policy formulation and innovation and invention were significantly influencing management of intellectual property of SMEs. The significance value was less than 0.05 an indication that the model was statistically significant.

\section{Coefficients}

\begin{tabular}{|c|c|c|c|c|c|c|}
\hline & \multirow{2}{*}{ Model } & \multicolumn{2}{|c|}{$\begin{array}{c}\text { Unstandardized } \\
\text { Coefficients }\end{array}$} & \multirow{2}{*}{$\begin{array}{c}\text { Standardi } \\
\text { zed } \\
\text { Coefficien } \\
\text { ts } \\
\text { Beta }\end{array}$} & \multirow{2}{*}{$\mathbf{t}$} & \multirow{2}{*}{ Sig. } \\
\hline & & B & $\begin{array}{l}\text { Std. } \\
\text { Error }\end{array}$ & & & \\
\hline \multirow{5}{*}{1} & (Constant) & .455 & .231 & & 1.973 & .106 \\
\hline & $\begin{array}{l}\text { Awareness } \\
\text { Creation }\end{array}$ & .416 & .009 & .444 & 1.815 & .009 \\
\hline & Funding & .182 & .050 & 1.231 & 3.616 & .036 \\
\hline & $\begin{array}{c}\text { Policy } \\
\text { Formulation }\end{array}$ & .053 & .017 & 1.075 & 3.159 & .025 \\
\hline & $\begin{array}{c}\text { Innovation } \\
\text { and } \\
\text { Inventions }\end{array}$ & .204 & .240 & .230 & .850 & .028 \\
\hline
\end{tabular}

From the data in the above table the established regression equation was

$\mathrm{Y}=0.455+0.416 \mathrm{X}_{1}+0.182 \mathrm{X}_{2}+0.053 \mathrm{X}_{3}+0.204 \mathrm{X}_{4}$

From the above regression equation it was revealed that holding funding, awareness creation, policy formulation and innovation and invention to a constant zero, management of intellectual property of SMEs would stand at 0.455 , a unit increase in awareness creation would lead to increase in management of intellectual property of SMEs by a factor of 0.416 , unit increase in funding would lead to increase in management of intellectual property of SMEs by a factor of 0.182 , a unit increase in policy formulation would lead to increase in management of intellectual property of SMEs by a factor of 0.053 and unit increase in innovation and invention would lead to increase in management of intellectual property of SMEs by a factor of 0.204 . At $5 \%$ level of significance and $95 \%$ level of confidence, funding had a 0.036 level of significance; innovation and inventions showed a 0.028 level of significance, policy formulation had a 0.025 level of significance while awareness creation showed 0.009 level of significance hence the most significant factor is awareness creation.

\section{Conclusions}

From study findings, the study concludes that community workshops should be held to raise awareness of the economic importance of intellectual property and to increase stakeholders' participation in the intellectual property policy making process. Further the study concludes that to be acceptable, any system of intellectual property rights has to strike a balance on the one hand, between providing incentives and rewards to the rights holder and on the other hand facilitate access to, and widespread diffusion and adoption of the fruits of creativity and innovation. Finally, in order for a firm to effectively manage its intellectual property it needs to establish a comprehensive policy which will provide guidelines on how to handle intellectual property and that the costs of patenting are generally perceived as one of the greatest barriers for SME.

\section{Recommendations}

The study recommends that an intellectual property policy statement should provide direction to the entire workforce on the importance of intellectual property and the practices for protecting and managing intellectual property assets. Further the study recommends that any company wishing to prosper in a highly competitive and globalized environment has to efficiently manage its intellectual property portfolio.

\section{Acknowledgements}

I acknowledge the support of my supervisor, Mr. Kepha Ombui of Jomo Kenyatta University of Agriculture and Technology.

\section{References}

[1] Alikhan, S., and Mashelkar, R. (2004). Intellectual Property and Competitive Strategies in the 21st Century. Global Intellectual Asset Management Report, 10(4), 1 -5

[2] Arundel, H., and Steinmueller, F. (2008). The Use of Patent Information by European Small and Medium-sized Enterprises, Journal of Strategic Analysis \& Strategic Management, 10 (2), 157-173

[3] Bainbridge, D. (2009). Intellectual Property ( $7^{\text {th }}$ Ed.). Harlow, London: Pearson Longman

[4] Blackburn, R. (2010). Intellectual Property and Innovation Management in Small Firms. London; Routledge

[5] Bosworth, D., and Webster, E. (2006).The Management of Intellectual Property. Cheltenham: Edward Elger Publishers Business Administration

[6] Cohen W., et.al (2000), Protecting their Intellectual Assets: appropriability Conditions and Why U.S. Manufacturing Firms Patent (or Not), NBER Working Paper 7552

[7] Cordes J., Hertzfeld H., andVonortas, N. (1999). Survey of High Technology Firms. Journal of technology, 13, 214-238

[8] Denscombe, M. (2007). The Good Research Guide: For Small-Scale Social Research Projects (3rd Ed.) New York: McGraw-Hill

[9] Easterby-Smith, M., Thorpe, R., \& Jackson .R .P. (2008). Management Research ( $3^{\text {rd }}$ Ed.). London:Sage estimates for European firms. Research Policy 27:127-141. 
[10] Fedrick, M. (2008). Competitive Advantages From Intellectual Property.California, Sheldon Mak Rose \& Anderson

[11] Finney, R. Z., Campbell, N. D., and Powell, C.M., (2004). Strategies and Resources: Pathways to Success. Journal of Resources Research, 11, 1-15.

[12] Ganguli, P. (2001). Intellectual Property Rights: Unleashing the Knowledge Economy. New Delhi, McGrawHill.

[13] Gosselin, A.,et.al (2008). Maximizing the Value of Intellectual Property: Assessing and Improving Intellectual Property Management Practices, 31:129-141

[14] Grindley, P., \& Teece, D. (1997). Managing Intellectual Capital: Licensing and Cross-Licensing in Semiconductors and Electronics. California: Graduate School of Business Administration, University of California

[15] Hillstrom, K., Hillstrom, L. (2 ${ }^{\text {nd }}$ Ed.): (2001). Encyclopaedia of Small Business ( Vol 2).Connecticut: Thomson Learning

[16] Idris, K. (2003, June) Intellectual Property: A Power Tool for Economic Growth .WIPO, 888.1, 5-13. Industrial R\&D", Brookings Papers on Economic Activity, pp. 783820 .International Chamber of Commerce. Intellectual Property: Source of innovation, creativity, growth and progress. Retrieved from http:// www.icc-cs.org

[17] Iron, M. (2004). Building an Intellectual Property Management Strategy. Retrieved from http:/ www.iaitam.org/Building_Intellectual_Property_Mgmt__Iron_Mountain. Html

[18] Jolly, A. and Philpott, J. (2004). A Handbook of Intellectual Property Management: Protecting, Developing and Exploiting Your intellectual property Assets. London, Kogan Page Publishers

[19] Kamiyama, S., J. Sheehan \& C. Martinez (2006), Valuation and Exploitation of Intellectual Property, OECD Science, Technology and Industry Working Papers, 2006/05, OECD Publishing. http://dx.doi.org/10.1787/307034817055
[20] Kiberenge, K. (2010). Students Take Fight to Mobile Company Over Invention. The Standard. Retrieved from www.standardmedia.co.ke on $20^{\text {th }}$ November, 2012.

[21] Krattiger, A. (2007). Intellectual Property Management in Health and Agriculture: A Handbook of Best Practices. Oxford: MIHR

[22] Ledergerbe H., (2003) The Swiss Federal Institute of Intellectual Property's new search

[23] Maskus, K. E. (2000). Intellectual Property Rights in the Global Economy, Washington, DC: Institute for International Economics

[24] Mulundu, L. (2010, October 18). Battle of Santas in Spaghetti Trademark and Branding Row. The Daily Nation. Retrieved from www.nation.co.ke on $20^{\text {th }}$ November, 2012.

[25] PricewaterhouseCoopers. (2007). Exploiting Intellectual Property in a Complex World. Technology Executive Connections, 4, 28-40

[26] Trott, P. (2008). Innovation Management and New Product Development $\left(4^{\text {th }}\right.$ Ed.).New Jersey: Prentice Hall

[27] Turku School of Economics and Business Administration. (2003). The Contribution of Copyright and Related Rights to the European Economy. Turku, Finland:

[28] Wilson, S., (2007). Value, Protect, Exploit: How Managing Intellectual Property can Build and Sustain Competitive Advantage. United States: Deloitte and Touché, Department of Technology Research and Thought Leadership. Management Journal, 6 (2), 201-210

[29] World Intellectual Property Organization. (2004).WIPO Intellectual Property Handbook: Policy, Law and Use. WIPO 489 (E), 3

[30] Yager, L. (2007). Intellectual Property: National Enforcement Strategy Needs Stronger Leadership and More Accountability. Pennsylvania: Diane Publishing 